Table 1. Fecundity and Primordial Germ Cent Numbers in Threg Species of Lampreys

\begin{tabular}{|c|c|c|c|c|c|c|}
\hline \multirow[b]{2}{*}{ Species } & \multirow[b]{2}{*}{$\begin{array}{l}\text { Adult egg } \\
\text { numbers }\end{array}$} & \multirow{2}{*}{$\begin{array}{l}\text { Fecundity } \\
\text { Larval oocyte } \\
\text { numbers }\end{array}$} & \multirow[b]{2}{*}{$\begin{array}{l}\text { Estimated total } \\
\text { germ cell numbers }\end{array}$} & \multicolumn{3}{|c|}{ Counts of primordial germ cells } \\
\hline & & & & $\begin{array}{l}\text { Number of } \\
\text { animals }\end{array}$ & $\begin{array}{l}\text { Mean and } \\
S . E \text {. }\end{array}$ & Range \\
\hline $\begin{array}{l}\text { L. planeri } \\
\text { L. fluviatilis } \\
P . \text { marinus (landlocked form) }\end{array}$ & $\begin{array}{c}1,000-3,000 \\
11,000-26,000 \\
21,000-107,000\end{array}$ & $\begin{array}{c}5,000-10,000 \\
7,000-42,000 \\
114,000-165,000\end{array}$ & $\frac{30,000}{500,000}$ & $\begin{array}{r}44 \\
13 \\
7\end{array}$ & $\begin{array}{l}51 \cdot 4 \pm 3 \cdot 3 \\
26 \cdot 5 \pm 4 \cdot 2 \\
54 \cdot 1 \pm 5 \cdot 6\end{array}$ & $\begin{array}{r}10-94 \\
7-49 \\
27-69\end{array}$ \\
\hline
\end{tabular}

mean germ cell number for this species (51) wes rather higher than the figures given by Beard ${ }^{15}$ and Okkelberg 5 for the primordial germ cells of brook lampreys. In spite of its greater fecundity, the river lamprey, $L$. fluviatilis, gave significantly lower counts than $L$. planeri (Table 1 ) and a similar trend was also observed in some preliminary observations made during the preceding year. Counts on the larvae of $P$. marinus showed no significant differences compared to oither of the other two species. There are, therefore, no grounds for believing that the number of primordial gorm cells bears any direct relationship to the number of definitive germ cells characteristic of the three species, although the possibility cannot be excluded that within a particular spocies the wide range of observed germ cell numbers might have some influence on the fecundity of individual animals.

School of Biological Sciences,

M. W. Hardisty

J. CosH

University of Bath.

'Ifughes, G. C., J. Embryol. exp. Morph., 11, 513 (1963).

2 Beaumont, H. M., and Mandl, A. M., Proc. Roy. Soc., B, 155, 557 (1962).

' Franchi, I. L., Mandl, A. M., and Zuckerman, S., in The Ovary, edit. by Zuckerman,'s. (New York and London, Academic Press, 1962).

4 Hardisty, M. W., J. Zool., 146, 346 (1965).

- Okkelberg, P., J. Morph., 35, 1 (1921).

' Hardisty, M. W., J. Zool., 146, 305 (1965).

' Hardisty, M. W., Evolution, 17, 17 (1963).

s Hardisty, M. W., Arch. Hydrobiol., 60, 340 (1964).

- Vladykov, V., Canad. Fish. Cult., 10, 1 (1951).

${ }^{19}$ Mintz, B., Arch. Anat. Micr. Morph. Exp., 48, 155 (1959).

${ }^{11}$ Mintz, B., and Russell, E. S., J. Exp. Zool., 134, 207 (1957).

${ }^{13}$ Bounoure, L., Aubry, R., and Huck, M., J. Embryol. exp. Morph., 2, 245 (1954).

${ }^{13}$ Blackler, A. W., and Fischberg, M., J. Embryol. exp. Morph., 9, 634 (1961).

${ }^{14}$ Hardisty, M. W., Nature, 191, 1215 (1961).

${ }^{16}$ Beard, J., Anat. Anz., 21, 189 (1902).

\section{Dwarf Eggs and the Timing of Ovulation in the Domestic Fowl}

Tre production of oggs considerably smaller than the normal has been reported in various birds ${ }^{1}$ and has been well documented for the domestic fowl ${ }^{2}$. Such eggs have been described as "witch eggs", "cock eggs", "dwarf eggs" and "wind eggs"- the latter term also being applied to infertile eggs ${ }^{3}$. It was known as early as the seventeenth century $^{8}$ that the yolks of such eggs were frequently absent, but that there was a central nucleus around which albumin was secreted. In an investigation of 236 dwarf eggs, Pearl and Curtis ${ }^{2}$ reported that 35 per cent of all dwarf eggs were without a yolk, 55 per cent contained froe yolk and 15 per cent had a complete yolk.

During recent observations on the time of oviposition in a group of hens, five were observod to lay dwarf eggs. The degree of calcification varied from a soft-shelled to a normal-shelled egg. On opening, the eggs were free from yolk but possessed a nucleus of solid material around which albumin had collected. No eggs weighed more then $25 \mathrm{~g}$.

The eggs wore not laid at any particular point in the clutch, and on examination of the time of lay it was found that this time was very close to that expected for tho laying of an egg following a normal oviposition. This is illustrated by the data in Tables 1 and 2 . In Table 1 is given the actual time of oviposition of all eggs including the dwarf eggs in each clutch, and in Table 2 is given the period of "lag"" found and expected botween the laying of the dwarf oggs and the preceding and succeeding oviposition. The time of "expected lag" was calculated on the basis of a normal ovulation occurring. It will be seen that the production of the dwarf egg in no way altered the timing of the subsequent ovulation.

The normally low incidence of dwarf eggs, less than 0.1 per cent ${ }^{2}$, has not in the past permitted many investigations to be made as to their cause. Pearl and Curtis ${ }^{2}$, from an examination of autopsied hens, concluded that the eggs were probably formed as a result of an ovulation occurring at the normal time but depositing the yolk in the body cavity with debris entering the oviduct. This would appear to be a reasonable explanation both for their production and for their oviposition at the expected time.

Table 1. TIMr of Oviposition of DWarf Egas in Clutches laid by

\begin{tabular}{|c|c|c|c|c|c|c|c|}
\hline & & Tim & of ovip & NS & Follicle ( & & \\
\hline Bird No. & $C_{1}$ & $C_{2}$ & $C_{3}$ & $C_{4}$ & $C_{5}$ & $C_{6}$ & $C$, \\
\hline 1 & - & $11 \cdot 15$ & $13 \cdot 15$ & $14 \cdot 00$ & $|\overline{17 \cdot 30}|$ & & \\
\hline 2 & - & - & $11 \cdot 30$ & $12 \cdot 00$ & $13 \cdot 15$ & $\overline{14 \cdot 00}$ & $16 \cdot 45$ \\
\hline 3 & - & $\overline{09 \cdot 00}$ & $11 \cdot 30$ & 16.00 & $16 \cdot 30$ & - & - \\
\hline $4_{1}^{*}$ & 88.00 & $|\overline{09 \cdot 30}|$ & $11 \cdot 00$ & $12 \cdot 15$ & $16 \cdot 00$ & & \\
\hline $4_{2} *$ & $08 \cdot 00$ & $\overline{09 \cdot 15}$ & $\overline{10 \cdot 30}$ & $12 \cdot 30$ & & & \\
\hline 5 & $10 \cdot 30$ & $\mid \overline{13 \cdot 30}$ & & & & & \\
\hline
\end{tabular}

The nomenclature $C_{1}, C_{2}$, etc., is that used by Fraps (ref. 4) and designates the first, second, etc., ovum in the clutch. A dash indicates a missing time. Dwarf eggs are enclosed in a panel.

* This bird laid a dwarf egg in two successive clutches reccrded here as 4, and 4 .

Table 2. Calculated and Observed lag in the Production of Dwarf EGGS

Bird No.

\begin{tabular}{|c|c|c|}
\hline ird No. & \multicolumn{2}{|c|}{$\begin{array}{l}\text { Lag between dwarf egg } \\
\text { and previous egg }\end{array}$} \\
\hline & Found & Expeeted \\
\hline 1 & $\begin{array}{l}27 \cdot 5 \\
26 \cdot 25\end{array}$ & $\begin{array}{l}26 \cdot 25 \\
25 \cdot 0\end{array}$ \\
\hline 4 & $\begin{array}{l}25 \cdot 5 \\
25 \cdot 25\end{array}$ & $\begin{array}{l}25 \cdot 5 \\
25 \cdot 25\end{array}$ \\
\hline
\end{tabular}

Lag between dwarf egg and succeeding egg

$\begin{array}{ll}26.75 & 25 \cdot 75 \\ 25 \cdot 5 & 25 \cdot 5 \\ 26.5 & 25 \cdot 75 \\ 28 \cdot 0 & 27 \cdot 75 \\ 27.5 & 27.5\end{array}$

The term "lag" is used as described by Fraps (ref. 4) and denotes the time in hours between one oviposition and the next.

Present theories for the control of ovulation in the fow ${ }^{5}$ place varying emphasis on the role of the oviducal egg, which has been ascribed a major ${ }^{6}$ and a minor ${ }^{5}$ role in controlling the time of ovulation. If dwarf eggs are produced without an accompanying ovulation, their appearance at the expected point in the clutch might be taken as support for the hypothesis ascribing a major role to the oviducal egg. On the other hand, if they are accompanied by an ovulation into the body cavity no major significance can be attached to their appearance.

A search of the literature has not revealed any further data on the precise time of production of dwarf eggs, and it is hoped that this communication will encourage the collection and publication of further data relating to the time of oviposition and the origin of these relatively rare curiosities.

Twyford Laboratories, Ltd.,

K. A. ROoKLEDGE

P. J. Heali

Twyford Abbey Road, London, N.W.10.

${ }^{1}$ Romanoff, A. L., and Rcmanoff, A. J., The Avian Egg, 257 (Chapman and Hall, Ltd., London, 1949).

${ }^{2}$ Pearl, R., and Curtis, M. R., J. Agric. Res., 6, 977 (1916).

${ }^{3}$ ind, (1600), 2, Book XIV (Univ. Oklahoma Press, 1963).

4 Fraps, R. M., Progress in Physiology of Farm Animals, edit. by Hammond J., 661 (Butterworths Seientific Publications, London, 1955).

' Fraps, R. M., Ovulation in the Domestic Fovol in Control of Ovulation, edit. by Villee, C. A., 133 (Pergamon Press, London).

"Nalbandov, A. V., in Comparative Endocrinology, edit. by Gorbman, A., 16 (John Wiley, New York, 1959). 